\title{
Adin nagusitasuna betetzen dutenean zer? Gazte etorkin tutelatu ohien gizarteratze erronka kontrako testuinguru sozioekonomiko batean ${ }^{1}$
}

\author{
What happens when they come of age? Social integration \\ challenge of unaccompanied young foreigners in an adverse \\ socioeconomic context
}

Maddalen Epelde Juaristi · maddalen.epelde@ehu.eus UNIVERSIDAD DEL PAÍS VASCO/EUSKAL HERRIKO UNIBERTSITATEA SOZIOLOGIA II SAILA

Recibido: 21-03-2016

Aceptado: 17-05-2016

\section{Laburpena}

Artikulu honen helburua Euskadiko gazte migratzaile tutelatu ohien gizarteratze egoera ezagutzea da. Espainia zein Euskal Herrira adin txikiko izanik iristen diren mutikoak dira hauek, baldintza horrek babesa ematen dielarik 18 urte bete arte; adin horretara iristean ordea gaitasun juridiko osoa eskuratu eta babesgabetasun egoeran aurkitzen dira bat-batean. Horri, gaur egun gizartea murgilduta dagoen krisi ekonomikoa gehitu behar zaio, gazte hauei zuzenean eragiten dien gertaera. Lan honetan, kolektibo honek emantzipazio zein gizarteratze prozesuei aurre egiterakoan pairatzen duen bulnerabilitate egoera aditzera eraman nahi da; aldi berean, familia autoktonoekin harremantzeko aukera izan dutenek eskuratzen duten gizarte laguntasuna eta horrek euren gizarteratze prozesurako duen eragin positiboa nabarmentzea ere bilatzen da; eta azkenik, gazte horiei baliabide gehiago eskaintzeko eta gizarte egoera berrira egokituko diren gizarteratze estrategiak sustatzeko dagoen beharra adierazi gura da. Guzti hori gazte etorkinei, euren hezitzaileei zein gaian adituak diren pertsonei burututako elkarrizketen azterketatik abiatuta.

Hitz gakoak: Gazte etorkin tutelatu ohiak, gizarteratzea, krisi ekonomikoa, emantzipazio baliabideak, familia autoktonoekin harremanak

\begin{abstract}
The current article aims to investigate the situation of social integration of unaccompanied young foreigners who are in the Basque Country. They are youngsters who arrive to Spain/Basque Country being minors, condition that provide them protection until they reach the age of majority. At this moment, they automatically get full legal capacity and they find themselves helpless. Moreover, the current socioeconomic context, which is characterized by a deep economic crisis, it seriously harms them. The objective is to show the vulnerability presented by young migrants tackling the process of emancipation and social integration. It is also wanted to demonstrate how the social support acquired from the relationships maintained with autochthonous families helps them face that processes. In this regard, it is noted the need to provide more resources and change integration strategies so that they adapt to the new social context. The information has been collected from an analysis of interviews conducted to young migrants, social educators and experts in the field.
\end{abstract}

Key words: Unaccompanied young foreigners, social integration, economic crisis, emancipation resources, relationships with autochthonous families

\footnotetext{
${ }^{1}$ Artikulu honetako ideia-ekarpenak autoreak Euskadiko IKEDAM ohien gizarteratzeari buruz burututako tesiaren parte dira; horretarako, Euskara eta Eleaniztasuneko Errektoreordetzak euskarazko tesia egiteko ikertzaileak prestatzeko laguntza jaso duelarik.
} 


\section{SARRERA}

Azken hamarkadetan, bizitza hobeago baten bila beste herrialde batetara bakarrik emigratzeko erabakia hartu edo horretara behartuta sentitu diren adingabe atzerritarrak agertu dira mapa migratorioan; herrialde hartzaileek Inoren Kargura Ez Dauden Adingabe Migratzaile (IKEDAM) izendatu dituztenak (Quiroga et al., 2009). Ez da estatu espainiarreko gertaera isolatu bat, eta herrialde txiro eta aberatsen arteko muga existitzen den beste zenbait puntu geografikotan ere gertatu da, hala nola, Europako zenbait tokitan (Alemania, Danimarka, Frantzia, Italia, Belgika, Suitza, Ingalaterra, Irlanda, Portugal edota Espainian); baita Estatu Batuetako zenbait herrialde edo Argentinan ere. Hala eta guztiz, europar herrialdeen artean Espainia IKEDAMen jasotzaile nagusietarikoa izan da (Quiroga et al., 2005), eta bere baitan Euskal Autonomia Erkidegoa (EAE) hartzaile printzipalen baitan aurkitzen da (Quiroga et al., 2011). Beraz gure herrian pisu handia duen eta euren egoera gertuagotik ezagutu asmoz ikertzea funtsezkoa den fenomenoa dugu esku-artean.

Kolektibo honen agerpenak eztabaida soziala, politikoa eta mediatikoa eragin du EAEn. Adingabe migratzaile hauei lotuta agertutako zenbait istiluk oihartzuna izan dute komunikabideetan. Ekintza horien artean aipa daitezke hainbat harrera zentroren gurariazko su-emateak, hala nola, Gipuzkoan Lazkaon (El País, 2008ko uztailak 4) eta Seguran (El País, 2008ko otsailak 8) gertatutakoak, edota Bizkaiko Arcentales (2008) edo Amorebieta (El Correo, 2006ko urriak 9) udalerrietan. Jokabide biolentoak ere izan dira, Tolosan adin txikiko batek hezitzaile zein zaintzaileak, eta baita zentroko beste kide batzuk labanaz zauritu zituenekoak esaterako (Diario Vasco, 2007ko urriak 1). Eta lapurretak ere gertatu dira, baita bortxaketaren bat ere, batik bat Gipuzkoako herrietan (El País, 2009ko martxoak 23).

Nahiz eta gutxienekoak eta puntualak izan, gertaera horiek kolektibo osoaren estigmatizazioa eragiten dute (Moreno, 2012). Komunikabideek eskainitako ikuspegian IKEDAM problematikoekin erlazionatutako berriak nagusitu izan dira. Eta arazoak dituzten gazte migratzaileak gutxiengoak izanik ere (Eusko Jaurlaritza, 2009), horrek kolektiboarekiko irudi orokorra negatiboa izatea eragin du, adin txikiko migratzaileak bizikidetza normalizaturako mehatxu gisa ikustea, eta etorkinen artean gaizkien baloratutako kolektiboetariko bat bilakatzea. Testuinguru horretan, gazte hauentzat zentroak edo baliabideak ezartzerako unean kontrako jarrera ugari izan da herri ezberdinetan. Eta guzti horrek badu eraginik euren gizarteratze prozesuak gauzatzerakoan.

Baina bestelako eztabaida ere eragin du fenomenoak, batik bat immigrazio edota haurtzaro/nerabezaroaren inguruan lan egiten duten eragile edo instituzioen aldetik, eta oroz gain adin txikiko hauei ematen zaien arretari lotuta. Ezbaian jarri da esaterako adina determinatzeko frogen fidagarritasun maila; zenbait eskubideren urraketa; zentroen kokapena, askotan leku isolatuetan ezarri direlarik eta hori integraziorako oztopo suertatu delarik; Autonomia Erkidegoen artean adingabeko hauen lekualdatzeak edo bermerik gabe burututako aberriratzeak burutzea; tutelak onartzerakoan ez-betetzeak eta erresidentzia baimenak eskatzerakoan atzerapenak; edota familietan abegi emateko aukerak (Ararteko, 2011 eta 2013; Bravo et al., 2010; Mazkiaran, 2011; Unicef eta CGAE, 2009). 
Hori horrela, hainbat izan dira azken urteetan aipaturiko fenomenoaren inguruan ikertu eta idatzi duten autoreak. EAEn harrera egindako IKEDAMen egoerak lehentasunezko arreta berezia jaso du Ararteko erakundearen eskutik (Euskal Herriko herriaren defendatzailea), txosten bereziak (Ararteko, 2005 eta 2011) kaleratu dituelarik, eta instituzio bereko Haur eta Nerabeentzako Bulegoak jarraipen zein urtekariak burutzen dituelarik. Beste zenbait autore ere arduratu dira fenomenoa ikertzeaz, batik bat mutiko² hauek aurkezten dituzten fluxu eta profilak aztertu dituztelarik (Gonzalo et al., 2010; Quiroga et al., 2009).

Aldiz, Ararteko-ren (2013, 2014 eta 2015) txosten edo gomendio orokorren bat salbuetsita, ez da ikerketa soziologiko gehiegirik burutu gazte hauek adin nagusitasunera iristean bizi duten errealitatearen inguruan. Haurtzaroaren babeserako sistemak harrera emandako adingabeen oinarrizko beharrak asetzen ditu 18 urte bete arte. Alabaina, arazoa behin adin nagusitasuna betetzen dutenean agertzen da, gauetik egunera euren errealitatea guztiz aldatzen baita, babes legal eta instituzional osoa izatetik kalteberatasun sozial, instituzional eta legalean egotera pasatzen direlarik, harrera gizartean integrazio prozesua erabat zailtzen diena. Hori dela eta, egoera berezi horretan aurkitzen diren subjektuen gizarteratze prozesuak zein baldintzetan ematen diren aztertzea du ikerketa objektutzat lan honek.

Ildo horretatik, ikerketaren lehendabiziko helburua IKEDAM ohiak gizarteratze prozesuari dagozkion esparru eta dimentsioetan zein egoeratan aurkitzen diren aztertzea da. Gazte hauek adin nagusitasuna betetzean aurkezten duten babes-gabezia egoeraz gain, gaur egungo testuinguru sozioekonomikoa kontutan hartzen da, krisi ekonomiko sakon batek ezaugarritzen duena. Gertaera horrek izan duen ondorio nagusienetarikoa enplegu tasaren jaitsiera izan da, eta horrenbestez, IKEDAM ohien gizarteratzea ahalbidetzen zuen tresna nagusia, enplegua, ez eraginkorra bilakatu dela edo gutxienik eraginkortasun maila galdu duela uste da.

Hala eta guztiz, EAEko kasuan baliteke gazte etorkin hauek pairatzen duten egoera ez izatea hain kontrakoa, izan ere, hiru lurralde historikoek emantzipazio baliabideak jarri dituzte martxan. Aldiz, baliabide horiek mugatuak direla eta ez direla gaur egungo testuinguru sozioekonomikora egokitzen planteatzen da, IKEDAM ohien gizarteratze eraginkor bat bermatzeko zailtasunak gehituko lituzkeena. Hori dela eta, baliabide horien nolakotasuna eta gazte etorkinen gizarteratze prozesuan nolako eragina duten ezagutzea ere nahi da ikerlan honetan.

Ikerketaren bigarren helburua Izeba ${ }^{3}$ proiektuan parte hartu duten IKEDAM ohiek pilatzen duten gizarte kapitala ezagutzea da, eta horrek gizarteratze prozesuan nola eragiten duen

\footnotetext{
${ }^{2}$ Soilik sexu maskulinoari egiten zaio erreferentzia, izan ere, estatu zein autonomia erkidego mailan \%85a baino gehiago mutilak dira; nesken presentzia oso txikia da (Ararteko, 2005; Gonzalo et al., 2010; Quiroga et al., 2009; Quiroga et al., 2011).

${ }^{3}$ Tutoretzapean dauden adingabeen osaba/izebak izateko eta haiei gizarteratzen laguntzeko prest dauden pertsona- edo familia-sarea da Izeba Proiektua. Erreferentzia- eta laguntza-familia horien eginkizuna hau da: ikasketak direla-eta, adibidez, gurasoengandik urruti bizi den iloba batengandik hurbil bizi den osaba/izeba batenaren antzekoa. Gipuzkoako Foru Aldundiko Gizarte Politika Departamentuak eta Baketik Fundazioak elkarrekin izenpetutako hitzarmenak abiarazten eta garatzen du ekimen hau. Informazio gehiago ondrengo helbidean: http://www.izeba.org/index.php?option=com_content\&view=article\&id=2\&Itemid=6\&lang=eu
} 
ulertzea. Proiektu horrek gazte etorkinak familia autoktonoekin harremanetan jartzea du helburu, eta hori horrela, adin txikiko ziren bitartean Izeba proiektuan parte hartzeko aukera izan zuten gazte etorkinek gainontzekoek baino gizarteratze egoera hobea aurkeztuko dutela planteatzen da, izan ere, familia autoktonoengandik gizarteratze esparru eta dimentsioetan bilakaera egokia izaten lagunduko dien gizarte laguntasuna jasoko dutela uste da.

Horretarako, lehenik eta behin marko teoriko bat landuko da, fenomenoak maila internazionalean, estatu mailan eta batik bat erkidego mailan izan duen bilakaera eta nolakotasuna aztertuz; eta lan honen helburuei jarraikiz zenbait kontzeptu teoriko landuz, hala nola, gizarteratzea zein gizarte kapital edo gizarte laguntasuna. Ondoren, ikerketa burutzeko erabilitako metodologia azalduko da, eta jarraian lanetik eratorritako emaitzak aurkeztuko dira, planteatutako helburuei jarraikiz. Amaitzeko, laneko ondorio nagusiak laburbilduko dira, eta baita esku-hartze proposamenak burutu ere.

\section{MARKO TEORIKOA}

Erreferente familiarrik gabeko adin txikiko hauen lekualdatzea azken urteetako migrazio internazionalen baitan ulertu behar da. Arango-ren (2007) hitzetan, azken urteetan migrazio internazionalak mundializatu egin dira, eta testuinguru horretan, tradizionalki emigrazio herrialde izan den espainiar estatua (Colectivo Ioé, 2008), eta nagusiki barne migrazioen jasotzaile izan den EAE (Ruiz Olabuénaga eta Blanco, 1994) migrazio internazionalen hartzaile bilakatu dira, zeintzuen baitan IKEDAMen etorrera barne-hartzen den.

Baina adingabe hauen etorrera orokorragoa den migrazio fenomenoaren baitan kokatzen bada ere, zenbait autorek besteengandik ezberdintzen den migrazio tipologia berezi gisa definitu dute. Suárez-ek (2006) dioenez IKEDAMek aktore migratorio berri bat eratuko lukete, motibazio eta helburu propioak dituena. Adin taldeetan oinarritutako solidaritatezko sare transnazionalen sorkuntzak, lan munduan txertatzeko modu propioak edo zeinu identitarioen araberako auto-errepresentazioak ezaugarrituko luke. Hori dela eta, Jiménez-en (2005) arabera adingabe hauek migrazio fenomeno internazionalaren baitako laugarren etapa bat xedatuko lukete. Lehendabizikoa, bakarrik zetozen gizonek eratuko zuten; bigarrena, horien emazte eta haurren berriz elkartzeek; hirugarrena, bakarrik zetozen emakumeek; eta azkenik, laugarrena, euren familiak jatorrian utzita bakarrik emigratu duten adingabeko pertsonek. Quiroga et al.-ek (2010), patroi ezberdinduaren ideia partekatuz, desberdintasun hori definituko lukeen faktore nagusia adin talde zehatz batekoak izatea litzatekeela diote, hau da, nerabezaro eta/edo gaztaroari dagokion etapan aurkitzea.

Europa mailan IKEDAMen fenomenoa asilo eskaerari lotuta agertzen da orokorrean. Hori erakusten dute Suedia, Alemania edo Ingalaterrak, besteak beste. Aldiz joera horretatik at geratzen dira Italia, Espainia eta neurri txikiagoan Frantzia (Senovilla, 2007); azken herrialde hauetan faktore ekonomikoa ageri da fenomenoaren azalpen nagusi gisa. Morenok (2012) aipatzen duen modura, herrialde horietan atzeko atetik burutzen diren fluxu migra- 
torioak gertatzen ariko lirateke. Atzerritartasun legediak horien sarbidean ezartzen dituen zailtasunak direla eta, zenbait kasutan, izaera familiarreko prozesu migratorioak adingabekoaren lekualdatzearen bidez ari dira gauzatzen, familiako buruak emigratu beharrean. Adin txikikoak proiektu hori gauzatzeko erraztasun gehiago izango ditu legediaren aldetik babesa jasoko duelako, eta gerora, familia osoaren proiektu migratorioa ahalbidetu ahal izango du. Hala eta guztiz, Espainiako kasuan ere, arrazoi ekonomikoez haratago, IKEDAMen emigrazio arrazoien atzean bestelako faktoreak ere nabarmentzen direla erakutsi dute zenbait ikerketa enpirikok (Quiroga et al., 2010); horien artean gizarte eta kultur aurreikuspenak hobetzea, arrazoi politikoa, etniko eta erlijiosoetatik alde egitea eta familia egoera korapilatsuetatik ihesi egitea aipatzen dira.

Espainian agerpena izan zutenetik (1993an agertu zen lehendabizikoa), adin txikiko hauen kopurua haziz joan da, nahiz eta hazkunde hori ez den izan uniformea, ezta jarraitua ere (Quiroga et al., 2011). 2008an erregistratzen da abegi emandako IKEDAMen kopuru gorena (8.080), eta urte horretatik aurrera beherakada bat ematen da, eta ez da 2009a geroztiko daturik ezagutzen (urte horretan 7.339 zeuden). Adingabe hauek estatuko autonomia erkidegoetan erakutsi duten banaketa desberdina da, eta hartzaile nagusien artean EAE aurkitzen da. Andaluzia izan da harrera herrialde nagusia, 1993 eta 2009 bitartean abegi emandakoen \%28a biltzen duelarik (Quiroga et al., 2011). Valentziar komunitateak jarraitzen dio \%16ari abegi eman diolarik ${ }^{4}$, Kataluniak \%11ari, EAEk eta Kanariek \%10ari eta Madrilek \%4ari.

EAEko egoera berezia da, izan ere, ez da Andaluzia edo Kanarien kasuan gertatzen den moduan mugako herrialdea, eta horrenbestez, etorkinak ez dira hasieratik bertara iristen; eta ez du Madril edo Bartzelona gisako hiriburu handirik ere, non IKEDAM kopuru handiago bat aurkitzea errazagoa izan daitekeen. Etorri diren etorkin adingabeak espresuki etorri dira. Hain zuzen, EAE haurtzaroaren babesean baldintzarik egokienak izateagatik adingabeengandik errekonozitutako komunitate autonomoa izan da (Ararteko, 2005; Quiroga et al., 2011). Horrek Espainiako beste leku batzuetan aurkitzen ziren IKEDAMak EAEra mugitzea eragin $\mathrm{du}$, baita jatorrizko herrialdetik zuzenean gazte etorkin gehiago etortzea ere, adingabe eta helduen migrazio sareetan zabaltzen ziren zurrumurruengatik.

Estatu mailan bezala, Haurtzaroko Gizarte Zerbitzu Foralek abegi emandako adingabe berrien kopurua handituz joan zen 2008 arte Euskadiko kasuan ere, nahiz eta ordutik aurrera gure lurraldera iristen diren adingabe migratzaileen kopuruak behera egiten duen, 2012an jadanik berdinduta dagoen gorakada txiki bat eman bazen ere (Ararteko, 2015). Horrela bada, kopuru hori 2008an iritsi zirenen erdian kokatzen da 2014an, 416 direlarik 2014an zehar Haurtzaroko Gizarte Zerbitzu Foralek abegi emandako mutikoak, 6 urte lehenago erregistratu ziren 806rekin alderatuz. Edonola ere, horien presentziak oraindik esanguratsua izaten jarraitzen du. Eta kontutan izan behar da adingabe iristen direnek adin

${ }^{4}$ Valentziar Komunitateko datuak ez dira errealak, izan ere, norbaiten kargura dauden adingabe migratzaileak ere kontabilizatu egiten dira IKEDAMekin batera. Gizarte Ongizateko Kontseilaritzak pisurik handiena IKEDAMena dela baieztatzen badu ere, datuak gutxi gorabeherakoak dira eta ez oso konparagarriak (Quiroga, et al., 2011: 180). 
nagusitasuna betetzen dutenean jada ez direla kontabilizatzen, baina askok gure artean jarraitzen dute eta arreta behar dute.

Jatorriei dagokionez, adin txikiko atzerritarren gehiengoa Marokotik datoz (Gonzalo et al., 2010; Quroga et al, 2009 eta 2011), horrek integrazioari begira eragin ditzakeen zailtasunekin; gurearengandik oso ezberdina den kultura batetik baitatoz, ohitura, erlijio eta hizkuntza desberdinekin. Horrek ezberdintasuna eragingo luke esaterako Inoren Kargura Ez Dauden bertako haurren egoerarekin eta gizarteratze prozesuekin alderatuz, azken horiek herrialdean jaiotakoak izanik kultura berbera partekatzen dute, hizkuntza badakite, dokumentazioarekin arazorik ez dute etab. Morenok (2012) aipatzen duen moduan kolektibo honentzako eskatzen den babesa ez da babes-gabezia egoeran dauden adin txikiko autoktonoentzat eskatzen denaren modukoa; jatorriaren araberako bereizketa nabarmena ematen delarik pertsona autoktono (herritarra) eta atzerritarraren (bestea, ez herritarra) artean.

Lan honen funtsa den gizarteratzearen gaiari helduz, hori tradizionalki lan-merkatuan txertatzeari lotuta egon da, enplegua gizarteratze mekanismo nagusi gisa kontsideratua izan delarik (Subirats, 2004). Hori dela eta, lan bat eskuratzea helburu duten ekintza eta politikak sustatu izan dira, beste aspektu batzuk gehiegi landu gabe. Horixe egin da IKEDAMen kasuan ere. Gaur egun enplegu bat eskuratzeko gehitu diren zailtasunak direla eta, ordea, komenigarria da potentzialtasun integratzailea duten eta mekanismo tradizionalen gabeziak osatzen dituzten elementu eta ekintzak ikertu eta horiekiko apustua egitea.

Ildo horretatik, garrantzitsua da kontutan izatea gizarteratzea pertsonen bizitzako aspektu ugari biltzen dituen dimentsio anitzeko kontzeptua dela (Blanco, 1990 eta 2001); horrela bada, beharrezkoa izango da kontzeptu hori dimentsio ezberdinetan banantzea. Horretarako lau dimentsio proposatzen ditu Blanco-k (2001), aldi berean gizarteratzeari dagozkion bi esparru orokorrago eratuko lituzketenak: esparru sozio-estrukturala eta esparru soziokulturala (Solé et al., 2002). Lehendabizikoaren baitan Blanco-k proposatzen duen egitura dimentsioa edo dimentsio sozioekonomikoa legoke, funtsean lan merkatuan txertatzeari erreferentzia egingo liokeena; eta bigarren esparruaren baitan gainerako hiru dimentsioak leudeke: gizarte dimentsioa (gizarte harremanen sarea), dimentsio kulturala (pauta kulturalak, tradizioak, ohiturak, hizkuntza) eta dimentsio identitarioa (errekonozimendua, identifikazioa, pertenentzia sentimendua). Blanco-k ageriko moduan aipatzen ez badu ere, dimentsio juridikoa IKEDAM ohien gizarteratze prozesuak ezagutzeko esparru sozio-estrukturalaren baitan kontutan izan beharreko dimentsioa dela uste da, izan ere, gazte horiek egoera juridiko erregularrean egotea egonkortasun gehiago lortzeko eta gizarteratzearen gainontzeko esparru eta dimentsioetara sarbidea izateko funtsezko aspektua izango da.

Dimentsio horiek bereizita, zenbait autorek pertsonen gizarte sarean eragitearen garrantzia nabarmendu dute (Castel, 1992 eta 1995; Subirats, 2004; EDE Fundazioa, 2011 eta 2012), zeintzuetatik gizarte kapitala eratorri eta metatzen den. Gizarte kapitala batik bat Bourdieu (1986) eta Coleman-ek (1988 eta 1990) definitutako eran ulertuta (horien artean ere desberdintasunak dauden arren): norbanakoak mantentzen dituen gizarte harremanetatik lor 
ditzakeen era askotariko abantailak, nagusiki onura pertsonala edo indibiduala dakartena, eta ez horrenbeste kolektiboa, komunitate edo nazioen mesederako dena, Putnam-ek (1993) hobesten duen modura; etorkinak bere gizarteratze prozesu indibidualerako abantaila lortuko duelako, baina ez onura kolektiboa (nahiz eta zentzu batean etorkinak erraztasunez integratzeak harrera gizartearen onura ere esan nahi duen).

Gizarte kapital kontzeptuaren paraleloan gizarte laguntasun kontzeptua aurkitzen dugu, nolabait gizarte kapitalaren ikuspegi psikosoziala litzatekeena; eta zenbait autorek bi kontzeptuen arteko bateragarritasunaren aldeko apustua egin dute ${ }^{5}$ (Bernat et al., 2010; Fuertes et al., 2013). Biak gizarte sare kontzeptuari estuki lotuta daude, naiz eta horrengandik bereizi. Autoreen artean desadostasun teorikoak agertzen badira ere, gizarte kapitalaren berezko ezaugarria da bere harremanezko izaera (Forni et al., 2004), izan ere, gizarte kapitala norbanakoen arteko harremanetan sortzen eta metatzen da. Ikuspegi soziologiko zein psikosozialetik, gizarte sareak gizarte harremanen egitura ezaugarri gisa ulertzen dira. Eta sare horiek gizarte laguntasunezko hartu-emanak gertatu eta gizarte kapitala pilatzeko eremuak izango dira. Gizarte kapitala stock aldagaia litzateke (metatutakoa, gizarte sareek denboraren une konkretu batean duten potentzialtasuna edo ahalmena), gizarte laguntasuna berriz fluxu aldagaiez irudikatuko litzateke, sare bateko kideen artean burutzen diren laguntasun transakzioak lirateke (Fuertes et al., 2013: 159). Gizarte sarea egitura litzateke, zeinaren baitan fluxu aldagaiak (gizarte laguntasuna) bideratzen diren, stock aldagaia, hau da, gizarte kapitala handitu edo txikitzea eragiten dutenak ${ }^{6}$.

Gizarte saretik mota ezberdinetako laguntasuna jaso ahal izango dute bertako kideek (Gracia et al., 1995), hala nola, emoziozko laguntasuna (sentimendu positiboak, maitasuna, errespetua); informaziozko laguntasuna (aholkua, informazioa, argibideak); eta laguntasun instrumentala (hornidura materialak, zuzeneko esku-hartzea).

Etorkinen gizarte sarearen inguruan burututako hainbat ikerketek erakutsi dute migrazio proiektua burutu ostean horien gizarte sarea txikia, homogeneoa eta dentsoa izan ohi dela (Martínez et al., 1996; Maya, 1999; Maya et al., 1999), gizarte kapitala metatzeko aukerak txikiagoak izatea eragiten duena. Horrenbestez, etorkinen gizarte sarean eragitea onuragarria suertatu daitekeela uste dute zenbaitek, izan ere, zabalagoa eta heterogeneoagoa den sare batetik gizarte kapital eta gizarte laguntasun gehiago eskuratu ahal izango dute (Bernat et al., 2010; Forni et al., 2004; Fuertes et al., 2013), harrera gizartean gizarteratzea erraztuko dien laguntasuna hain zuzen (Hernández et al., 2006). Hori dela eta, pertsonen gizarteratzea lan merkatu edo formakuntza bezalako faktore klasikoetatik haratago gizarte harremanen bidez ere sustatu daitekeela planteatzen da lan honetan.

\footnotetext{
${ }^{4}$ Lan honetan apostu berbera egin da, batik bat, gizarte laguntasunaren osagai funtzionalaren baitan bereizten diren laguntasun mota ezberdinek (Gracia et al., 1995) IKEDAMek izeba familien aldetik jasotzen dituzten laguntasun mota ezberdinak ezagutzeko eta sailkatzeko bidea ematen digutelako.

${ }^{5}$ Fluxu aldagaiak denboran zehar modu jarraituan sortzen direnak dira, stock aldagaiak berriz, denboran zehar une zehatz batekin harremantzen dira. Bien artean existitzen den harremana ondorengoa da: fluxuek stockak elikatzen dituzte, baina azken horiek fluxuak gertatzeko bidea ematen dute. Fluxuek stocken denborazko bariazio edo aldaketak irudikatzen dituzte beraz, horien gehikuntza edo murriztapenak (Fuertes el al., 2013).
} 


\section{METODOLOGIA}

Ikerketa hau aurrera eramateko metodologia kualitatiboaren erabilera egin da. Ikuspegi honen hautaketa aurrez aurkeztutako ikerketa helburu eta gaiaren ezaugarrien arabera burutu da. Blanco (1990) bezalako zenbait autorek metodologia kualitatiboaren erabilera hobesten dute etorkinek harrera gizarteetan erakusten dituzten gizarteratze prozesuen analisirako.

Baliatutako teknika elkarrizketa erdi-egituratua izan da, galdera zabalekin baina ordena zehatz bat jarraikiz; izan ere, teknika horrek elkarrizketatuei elkarrizketatzaileari ahoz egoeraren inguruko definizio pertsonala eskaintzeko bidea ematen die (Ruiz Olabuénaga, 1996). Elkarrizketak hiru lurralde historikoetan burutu dira, guztira 25, zeintzuen artetik 16 IKEDAM ohiak izan diren, eta gainontzekoak kolektiboari bideratutako programa ezberdinetako hezitzaile, tekniko zein koordinatzaileak, baita gaian aditu diren zenbait pertsonak ere. IKEDAM ohiak elkarrizketatzearen bitartez banakako egoera pertsonalak ezagutzea nahi izan da, profesional eta adituen bitartez berriz errealitatearen inguruko ikuspegi orokorrago bat jasotzea.

Landa lana 2013ko urriak 16tik 2014ko martxoak 20ra bitartean burutu da, eta elkarrizketa bakoitzaren iraupena 60 eta 90 minutu artekoa izan da. Jarraian aurkezten den 1 Taulan burututako elkarrizketa guztiak ikus daitezke, bakoitza kontaktatua izan den baliabidearen izena eta dagokien probintzia. IKEDAM ohien kasuan euren adina eta jatorrizko herrialdearen lehendabiziko letra ezarri da parentesi artean, "M" letrak Maroko-ri egiten diolarik erreferentzia, “K” letrak Kenia-ri eta "G” letrak Ghana-ri. Edonola ere, adin eta jatorriak ez dira izan aurrez pentsatuak, halabeharrez tokatu direnak baizik; horrek euren perfilen inguruko informazioa ere igortzen duelarik, Gipuzkoa eta Bizkaiko kasuan gehiengo nagusia marokoarrak, Araban berriz Sharaz hegoaldekoak. 
Taula 1. Elkarrizketatutako pertsonak lurralde historiko, programa eta kategoriaren arabera

\begin{tabular}{|c|c|c|c|}
\hline $\begin{array}{l}\text { Lurralde } \\
\text { historikoa }\end{array}$ & Programa/entitatea & Kategoria & Elkarrizketatuak \\
\hline \multirow{4}{*}{ BIZKAIA } & \multirow[t]{2}{*}{ Hemen programa (Bizkaiko elkarte ezberdinak) } & IKEDAM ohiak & $\begin{array}{l}\text { E2 }(20, M) \\
\text { E3 }(18, M) \\
\text { E4 }(21, M) \\
\text { E5 }(19, M)\end{array}$ \\
\hline & & Hezitzailea & E6 \\
\hline & \multirow{2}{*}{$\begin{array}{l}\text { Mundutik Mundura proiektua (Bizkaiko Foru } \\
\text { Aldundiak erakunde ezberdinekin hitzarmena } \\
\text { sinatuta, horien artean Goiztiri Elkartea) }\end{array}$} & IKEDAM ohiak & $\begin{array}{l}\mathrm{E} 19(19, \mathrm{M}) \\
\mathrm{E} 20(20, \mathrm{M}) \\
\mathrm{E} 22(20, \mathrm{M})\end{array}$ \\
\hline & & Hezitzailea & E23 \\
\hline \multirow{6}{*}{ GIPUZKOA } & \multirow{3}{*}{$\begin{array}{l}\text { Izeba proiektua (Baketik Fundazioa eta } \\
\text { Gipuzkoako Foru Aldundia) }\end{array}$} & Izeba-k & $\begin{array}{l}\mathrm{E} 12 \\
\mathrm{E} 21\end{array}$ \\
\hline & & IKEDAM ohiak & $\begin{array}{l}\text { E13 }(19, M) \\
\text { E24 }(21, M) \\
\text { E25 }(21, M)\end{array}$ \\
\hline & & Koordinatzailea & E18 \\
\hline & \multirow[t]{2}{*}{$\begin{array}{l}\text { Lortuz programa (Gipuzkoako Foru Aldundiak } \\
\text { erakunde ezberdinekin hitzarmena sinatuta, } \\
\text { horien artean Kolore Guztiak Elkartea) }\end{array}$} & IKEDAM ohiak & $\begin{array}{l}\text { E10 }(21, M) \\
\text { E11 }(26, M) \\
\text { E15 }(24, M) \\
\text { E16 }(19, M)\end{array}$ \\
\hline & & Teknikoa & E17 \\
\hline & Immigrazio teknikoa eta gizarte hezitzailea & Aditua & E14 \\
\hline \multirow{3}{*}{ ARABA } & \multirow[t]{2}{*}{ Aukera proiektua (Itaka Fundazioa) } & IKEDAM ohiak & $\begin{array}{l}\text { E7 }(19, \mathrm{~K}) \\
\text { E8 }(19, \mathrm{G})\end{array}$ \\
\hline & & Hezitzailea & E9 \\
\hline & Ararteko, Haur eta Nerabeentzako Bulegoa & Zuzendaria & E1 \\
\hline
\end{tabular}

Iturria: Egileak eginda.

Lehendabiziko helburua bete asmoz, burututako elkarrizketetan IKEDAM ohiek Blanco-k (2001) proposatutako gizarteratzearen dimentsio bakoitzean aurkezten duten egoeraren inguruan galdetu zaie informatzaileei. Gazte etorkinen gizarteratze prozesuan krisi ekonomikoak izan duen inpaktuari buruz ere galdetu zaie eta emantzipazio baliabideek prozesu horretan izan duen eraginaz ere bai.

Bigarren helburuari erantzuna emateko asmoz Izeba proiektuaren erabiltzaileak izan diren gazteak, izebak eta proiektuaren koordinatzailea elkarrizketatu dira; horrela, pertsona heldu autoktonoekin harremantzeak gazte etorkinen gizarteratze prozesuan nola eragiten duen ezagutzeko asmoz. Horretarako Gracia et al.-ek (1995) bereizitako laguntasun mota bakoitzaren baitan izeben aldetik jasotzen duten laguntza aztertu da, eta aldi berean, jasotako laguntasun horrek gizarteratzeari dagozkion esparru eta dimentsioetan nola eragiten duen ikusi da. 


\section{EMAITZAK}

\subsection{IKEDAM ohien gizarteratze egoera Euskadin}

\subsubsection{Esparru sozio-estrukturala}

Gazte hauekin harremanetan lan egiten duten profesional zein IKEDAM ohiek eurek diotenez dimentsio juridikoari dagokionean irregularizazio juridikorako joera hautematen da azken urteetan. Hezitzaileen arabera krisiarekin baimenak berritzea gero eta zailagoa bilakatu da. Lan merkatuan murgiltzeko aurkitzen dituzten zailtasunak eta emantzipazioko prestazio ekonomikoen kantitate urriak edo horiek eskuratzeko ezintasunak zuzenean eragin dute gazte hauen egoera juridikoan, izan ere, legediak gutxieneko bitarteko ekonomikoak izatea eskatzen du baimenak berritu ahal izateko irizpide gisa ${ }^{7}$.

Aurkezten duten lan egoera ere konplexua da, gehiengoa langabezian daudelarik. Krisiak eurengan izan duen eragina nabarmena da; hezitzaile, aditu eta gazte migratzaile eurek diotenez, orain dela urte batzuk, oparoaldi ekonomikoaren garaian, ez zen zaila eraikuntza, ostalaritza edo bestelako sektoreetan lanpostu bat aurkitzea, eta hain zuzen enplegua zen nagusiki gazte hauen gizarteratzea ahalbidetzen zuen tresna nagusia. Gaur egungo testuinguru sozio-ekonomikoak ordea zaildu egiten du enplegu bat eskuratu eta mantentzea, eta IKEDAM ohien enplegu tasa erabat jaitsi da krisi ekonomikoaren ondorioz; hezitzaileek diotenez \%90-95 ingurutik \%25-30 ingurura hain zuzen.

(El porcentaje de los que encuentran un empleo) ha bajado mogollón, sí, sí, totalmente, o sea... en picado. Si antes de los PCPIs salían el noventa y cinco por ciento con trabajo, ahora... un treinta puede ser... o sea, mucho vamos (E23) ${ }^{8}$.

Horrez gain, gazte hauek lana aurkitzerako orduan dituzten zailtasunak bikoiztu egiten dira. Alde batetik, IKEDAM ohiek eskura ditzaketen kualifikazio baxuko enpleguak krisiaren eraginez gehien murriztu direnak dira. Baina gainera, enpresari batek hauetariko mutiko bat kontratatzeko jarraitu beharreko prozesua luzea eta neketsua dela erakusten du ikerketak, horrek askotan pertsona autoktonoak aukeratzera daramatzalarik.

Entonces, las empresas que tiene que contratar a estos, tienen que tener más moral que el alcoyano, o sea, vamos, hacer todo el papeleo... o sea, tienen que estar muy convencidos para contratar a un chaval de estos, o sea, sino no... sino todo es muy engorroso, todo el papeleo y todo eso, es muy engorroso. Hay que estar luego dos meses hasta que llegan los papeles, tal... entonces, tienen muy difícil la integración laboral, lo tienen muy difícil (E12).

\footnotetext{
${ }^{7}$ Atzerritarren eskubide eta betebeharrei eta haien gizarteratzeari buruzko 2/2009 Lege Organikoa onartzen duen 557/2011 Dekretu Errealaren 197.2 artikuluak ezartzen duenaren arabera IKEDAM izan denaren erresidentzia baimena berritua izango da gazteak bere mantenurako OAEAParen (Ondorio Askotarako Errenta Adierazle Publikoa) \%100ari dagozkion bitarteko ekonomikoak dituela egiaztatzen duenean. 2015 urtean 532,51€koa litzateke kopuru hori.

${ }^{8}$ Lan osoan zehar agertuko diren elkarrizketatuen hitzak jatorrizko hizkuntzan mantentzeko erabakia hartu da, itzulpenak egiten hasi ezkero berezko adierazpenak galtzeko arriskua aurreikusi delako.
} 
Horrela bada, dimentsio ekonomikoari dagokionean ere egoera korapilatsuan aurkitzen dira gazte hauek orokorrean, eguneroko gastuei aurre egiteko zailtasunekin eta euren proiektu migratorioa motibatu zuen helburu nagusia bete ezinik: jatorrizko familiari dirua bidaltzea.

Pues... vives hasta aquí (señala el cuello con el dedo), ahogado, ahogado, claro, no tiene final. (E20).

Bizilekuari dagokionez ere egoera zailean aurkitzen dira, zenbait elkarrizketatu kalean bizitzen daudelarik edo egon direlarik uneren batean, horrek eragiten dituen arrisku guztiekin. Gazteetariko batzuk drogak kontsumitu izana aipatzen dute (kola edo disolbatzailea esnifatzea) hotzari eta beldurrari aurre egin eta pasatzen ari diren une gogorrak ahazteko asmoz.

\subsubsection{Esparru soziokulturala}

Gizarte dimentsioari dagokionean gazte etorkin hauen gizarte sarea gehien bat beste IKEDAM ohi batzuek eratzen dutela erakusten du ikerketak, adin txikiko ziren bitartean elkarbizi izan zuten zentruetan ezagutu zituztenak eta euren oso antzeko egoeran aurkitzen direnek hain zuzen. Nahiz eta zenbaitek formakuntza kurtsoetan edota futbolean jolasten ezagutu duten bertako jendearekin ere harremana badutela aipatzen duten, normalki autoktonoekin mantentzen duten harremana oso murritza da. Adin txikiko ziren bitartean eurentzako sortutako zentru espezifikoetan bizi izanak ez du errazten kontaktu hori; langabezian eta egoera juridiko irregularrean egoteak ere galarazten die harrera gizarteko jendearekin harremanak mantentzea (lan harremanen gabezia, kalera ateratzeko beldurra poliziak harrapatu eta jatorrizko herrialdera bidali ditzaketelako etab.). Guzti horrek gizarte isolamendua pairatzera eraman ditzake.

Pues antes salía, pero ahora ya como está la cosa, tampoco... Pues eso, no mucho, la verdad, no mucho. No, ahora tengo miedo que me pille la policía... Pues eso. Entonces hablamos en internet y eso un poco... (E4).

Autoktono eta IKEDAM ohien artean harremanik ez egoteak kulturarteko kontaktua ekiditen du; gazte etorkinei harrera gizarteko kultura eta ohiturak ezagutzea erabat zailtzen die horrek, eta aldi berean autoktonoek ere ezer gutxi jakin dezakete etorkinen jatorrizko tradizioei buruz. Guzti horrek jarrera arrazistak eragin ditzake, elkarrekiko sentsibilitaterik ez baita garatuko; hala baieztatzen dute hezitzaile, tekniko, izeba eta IKEDAM ohiek eurek.

Sales alguna noche o lo que sea y ves la gente que está cogiéndose su bolsa, que tiene miedo de que le robes o lo que sea, ¿sabes? En ese sentido sí que te sientes un poquito mal, pero bueno, yo creo que, no se, aquí en España en general es así, si te ven de diferente color ya creen que eres un ladrón o creen que eres... luego, no se, cuando te conoce la gente ya igual menos, ¿no? Porque ya saben cómo eres y tal, pero bueno. (E15).

Horrela bada, dimentsio kulturalean ez da gizarteratzerik eman, eta horrek aldi berean dimentsio identitarioaren baitako gizarteratzea ere oztopatzen du, hau da, gazte migratzaileak harrera gizarteko kide gisa identifikatzea eta aldi berean gizarte berriak bere baitan onartzea, Blanco-ren (1990) arabera etorkinen gizarteratze erreal batetaz hitz egin ahal iza- 
teko beharrezkoa litzatekeena. Bi kolektiboen artean kontaktu gutxi egoteak eta gainera askotan jarrera arrazisten biktima izateak IKEDAM ohiek harrera gizartea kontrako ingurune gisa hautematea eragiten du, eta horrek gizarte berriarekin identifikatzea eta bertako parte direneko sentimendua garatzea eragozten die. Gazte asko euren identitatea definitzerako orduan arazo larriekin aurkitzen direla erakusten dute elkarrizketek, izan ere, askotan ez dira identifikatzen ez harrera gizartearekin, ezta jatorrizkoarekin ere. Hezitzaile eta teknikoak ere jabetzen dira errealitate horretaz.

Sí que tienen ese problema, ¿eh? Es... "no soy ni de aquí, ni soy de allí”, y eso les va a perseguir siempre. (E17).

\subsection{Emantzipazio baliabideak}

EAE kontziente izan da gazte etorkin tutelatu ohiek adin nagusitasuna bete ostean pairatzen duten egoera zailaz, hori dela eta, Foru Aldundiek eta elkarte desberdinek kolektiboaren gizarteratze prozesuak laguntzen jarraitzeko baliabideak jarri dituzte martxan, nahiz eta lurralde historiko batetik bestera desberdintasunak nabarmentzen diren. Ondorengo 2. taulan bakoitzean eskuragarri dauden programa eta baliabideak laburbiltzen dira, kudeatzen dituzten entitateak, helburuak eta sarbide baldintzak zehazten direlarik.

Taula 2. EAEko emantzipazio baliabideak lurralde historikoen arabera

\begin{tabular}{|c|c|c|c|}
\hline $\begin{array}{l}\text { Lurralde } \\
\text { historikoa }\end{array}$ & Programa/baliabidea & Helburuak & Sarbide baldintzak \\
\hline \multirow{3}{*}{ BIZKAIA } & $\begin{array}{l}\text { Mundutik Mundura } \\
\text { (Diputazioa) }\end{array}$ & $\begin{array}{l}\text { - Bizilekuarekin lagundu } \\
\text { - Dokumentazioarekin lagundu } \\
\text { - Formakuntza eskaini } \\
\text { - Lan merkatura sarbidea }\end{array}$ & $\begin{array}{l}\text { Gazte tutelatu ohiak ( } 1 \\
\text { urte instituzionalki } \\
\text { babestuta; aldeko } \\
\text { jarrera) }\end{array}$ \\
\hline & Hemen (elkarteak) & $\begin{array}{l}\text { - Bizilekuarekin lagundu } \\
\text { - Dokumentazioarekin lagundu } \\
\text { - Formakuntza eskaini } \\
\text { - Lan merkatura sarbidea }\end{array}$ & $\begin{array}{l}\text { Gazte tutelatu ohiak } \\
(18-23)\end{array}$ \\
\hline & $\begin{array}{l}\text { Gizarte inklusiorako } \\
\text { Laguntza Berezia }(332,95 € \\
\text { hilean) (Diputazioa) }\end{array}$ & $\begin{array}{l}\text { Lanpostu bat eskuratu artean } \\
\text { egonkortasun ekonomikoa }\end{array}$ & $\begin{array}{l}\text { Gazte tutelatu ohiak } \\
\text { (18-23; Bizkaian } \\
\text { erroldatuta; Lanbiden } \\
\text { izena emanda) }\end{array}$ \\
\hline \multirow{3}{*}{ GIPUZKOA } & Lortuz (Diputazioa) & $\begin{array}{l}\text { - Bizilekuarekin lagundu } \\
\text { - Dokumentazioarekin lagundu } \\
\text { - Formakuntza eskaini } \\
\text { - Lan merkatura sarbidea }\end{array}$ & $\begin{array}{l}\text { Gazte tutelatu ohiak } \\
\text { (18-23; aldeko jarrera) }\end{array}$ \\
\hline & $\begin{array}{l}\text { Diru-laguntza (633€ hilean) } \\
\text { (Diputazioa) }\end{array}$ & $\begin{array}{l}\text { Lanpostu bat eskuratu artean } \\
\text { egonkortasun ekonomikoa }\end{array}$ & $\begin{array}{l}\text { Gazte tutelatu ohiak } \\
\text { (18-23; aldeko jarrera) }\end{array}$ \\
\hline & $\begin{array}{l}\text { Izeba (Diputazioa + Baketik } \\
\text { Fundazioa) }\end{array}$ & $\begin{array}{l}\text { Osaba-izeba gisa arituko diren } \\
\text { familia autoktonoekin } \\
\text { harremanak ezartzea }\end{array}$ & Adin txikiko tutelatuak \\
\hline \multirow{3}{*}{ ARABA } & $\begin{array}{l}\text { Diputazioaren harrera } \\
\text { erresidentzial eta } \\
\text { familiarraren ondorengo } \\
\text { jarraipen programa }\end{array}$ & $\begin{array}{l}\text { - Babes tutoriala } \\
\text { - Prestazio ekonomikoen } \\
\text { kudeaketa }\end{array}$ & $\begin{array}{l}\text { Gazte tutelatu ohiak } \\
\text { (baldintzak zehaztu } \\
\text { gabe) }\end{array}$ \\
\hline & $\begin{array}{l}\text { Diru-laguntzak } \\
\text { (etxebizitzaren alokairurako } \\
230 € \text {; jantokirako bonoak; } \\
\text { gastu pertsonaletarako } 75 € \text { ) } \\
\text { (Gasteizko Udala) }\end{array}$ & $\begin{array}{l}\text { Lanpostu bat eskuratu artean } \\
\text { egonkortasun ekonomikoa }\end{array}$ & $\begin{array}{l}\text { Gazte tutelatu ohiak } \\
\text { (baldintzak zehaztu } \\
\text { gabe) }\end{array}$ \\
\hline & Aukera (Itaka Fundazioa) & $\begin{array}{l}\text { - Bizilekuarekin lagundu } \\
\text { - Dokumentazioarekin lagundu } \\
\text { - Formakuntza eskaini } \\
\text { - Lan merkatura sarbidea }\end{array}$ & $\begin{array}{l}\text { Gazte tutelatu ohiak } \\
(18-21)\end{array}$ \\
\hline
\end{tabular}

Iturria: Egileak eginda. 
Emantzipazio baliabideak mugatuak direla ohartzen gara, izan ere sarbide baldintzak ezartzen dira, eta beraz, soilik irizpide horiek betetzen dituzten gazteak baliatu ahal izango dira horietaz. Bestalde, baliabideek soilik gizarteratzearen esparru sozio-estrukturalean eragiten dutela ikusten da, programa eta baliabide gehienek bizilekuarekin edota dokumentazioarekin laguntzea, formakuntza eskaintzea eta batik bat mutiko hauek lan merkatuan ahal bezain bizkorren txertatzea dute helburu, euren beharrei bere kabuz aurre egiteko ahalmena izan dezaten. Aitzitik, gaur egun lanpostu bat eskuratzeko dauden zailtasunak direla eta askotan ezinezkoa suertatzen da helburu hori betetzea.

Gainera, emantzipazio baliabideak denboran ere mugatuak dira, eta soilik denbora tarte batean izan daitezke gazte migratzaileak horien onuradun. Gehieneko denbora hori amaitzen denean berriro ere adin nagusitasuna bete zuteneko egoera berberean aurkitzen dira: edo lanpostu bat eskuratzen dute, gaur egun oso gutxik lortzen dutena; edo euren gizarteratze prozesuak etenda gelditzen dira, gizarte bazterkeria egoeran aurkitzeko arrisku larriekin.

Zentzu horretan aipagarria da E22-k aurkezten duen errealitatea. Adin nagusitasunera iristean emantzipazio baliabide ezberdinak eskuratzeko irizpide guztiak betetzen zituen, eta beraz, mutikoa Bizkaiko Mundutik Mundura programan sartzen da. Programa horretatik emantzipazio pisu baterako sarbidea kudeatzen diote, baimenak berritzen lagundu, eta gizarte inklusiorako laguntza berezia izapidetu. Formakuntza ere eskaintzen diote, gazteak ahal bezain laster lan merkatura sarbidea izan dezan.

Aldiz, denbora bat igaro ostean emantzipazio pisuan bizi ahal izateko gehieneko mugara iristen da, hori dela eta, elkarrizketako unean pisu partekatu batean bizitzen aurkitzen da, hilero $175 €$-ko alokairua ordainduz. Kontutan izanik jasotzen duen gizarte inklusiorako laguntza 331,25€-takoa dela, eta alokairuaren gastuaz haratago argia, gasa, ura, janaria edota arropa bezalako gastuei ere aurre egin behar diela, argi gelditzen da bere egoera ekonomikoa oso korapilatsua dela. Horri gehitu behar zaio hilabete batzuen buruan laguntza ekonomiko hori jasotzeko epea amaitzen zaiola, eta beraz, lanpostu bat eskuratzen ez badu, aurki inolako diru sarrerarik gabe aurkituko dela, eguneroko gastuei aurre egin ezinik. Gutxieneko bitarteko ekonomikoak dituela baieztatu ezinik erresidentzia baimenik ere ez diote berrituko, egoera juridiko irregularrean aurkituko delarik. Guzti horrek, adin txikiko zenetik jarraitu duen gizarteratze prozesua bertan bera gelditzea eragingo dio. Mundutik Mundurako gizarte hezitzailea oso kontziente da IKEDAM ohi hau laster aurkituko den egoera zailaz.

Sí, hasta ahora porque lo ha ido haciendo con Goiztiri ${ }^{9}$, pero ahora ya el día que tenga que renovar el permiso de residencia se lo van a denegar fijo, si no tiene trabajo le van a denegar, porque con la ayuda no llega al mínimo que tiene que llegar, y además se le acaba ya, sí, sí. E22 ya esta... sin ingresos económicos no puede renovar pero tampoco puede hacer frente a sus gastos. Y con lo difícil que está hoy en día encontrar un trabajo... su proceso de integración lo veo muy complicado. (E23)

${ }^{9}$ Mundutik Mundura programa aurrera eramaten duen elkarteetariko bat. 
Errealitatea asko sinplifikatuz, adin nagusitasuna bete ostean, IKEDAM ohiek nolabait hiru traiektoria jarraitu ahal izango dituztela ikusi da (1. Irudia): 1) Lanpostu bat eskuratu dutenek ohiko gizarteratze eredu tradizionalarekin jarraitu ahal izango dute; 2) Irizpideak bete eta emantzipazio baliabideetarako sarbidea dutenek egonkortasun sozioekonomikoa lortuko dute denbora tarte batean, erabiltzeko gehieneko epea bete arte. Horiek erabili ostean lanpostu bat eskuratzen badute gizarteratze prozesuan aurrera jarraituko dute lehendabiziko traiektoriari jarraitu diotenekin batera; aldiz enplegurik lortzen ez badute prozesu hori etenda geratuko da eta gizarte bazterkeria egoeran aurkituko dira gazteak. 3) Eta azkenik, adin nagusitasuna bete ostean enplegurik lortu ez dutenak eta emantzipazio baliabideetara sartzeko irizpideak betetzen ez dituztenak zuzenean gizarteratze prozesua etenda eta gizarte bazterkeria egoeran aurkituko dira. Gehienetan bigarren edo hirugarren traiektoriak jarraitzen dituzte IKEDAM ohiek, eta bigarren bideari jarraitzen dioten kasu gehienetan, gizarteratze prozesuaren garapen luzeago bat izan ostean hirugarren bideari jarraitu diotenekin batera aurkitzen dira: enplegurik gabe eta gizarte bazterkeria egoeran.

Irudia 1. IKEDAM ohien ibilbideak gizarteratze prozesuan

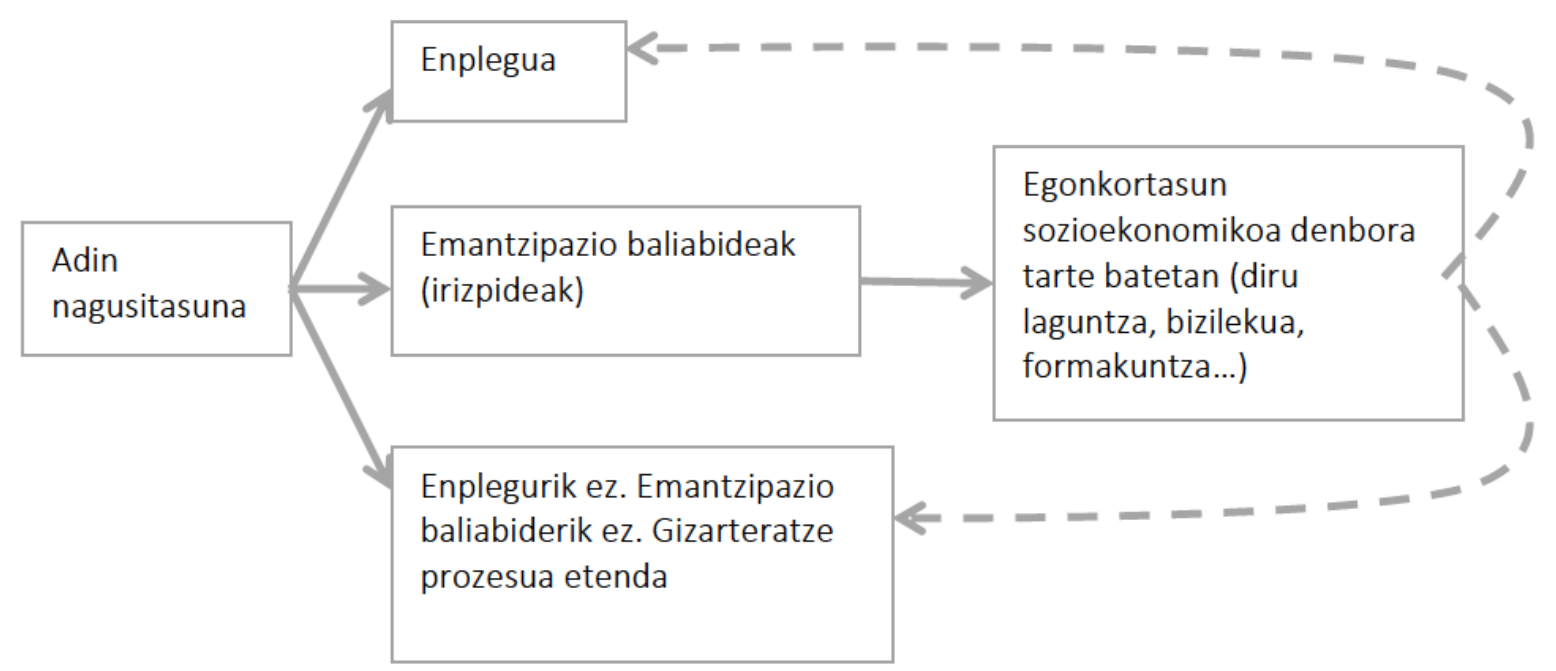

Iturria: Egileak eginda.

Zentzu horretan, gazte hauentzat eskuragarri legokeen izaera ezberdineko baliabide bakarra Izeba proiektua litzateke, gizarteratzearen esparru soziokulturalaren baitako gizarte dimentsioan eragiten duena. Aipaturiko proiektua 2009an jarri zen martxan Gipuzkoako Foru Aldundiko Gizarte Politika Departamentuak eta Baketik Fundazioak elkarrekin izenpetutako hitzarmenetik abiatuta. Proiektuaren helburua pertsona edo familia boluntarioen sare bat osatzea da, IKEDAMen osaba-izeba gisa aritzea onartuko dutenak. Proiektu hau Froland et al.-en (1981) boluntarioekin loturak ezartzeko estrategiarekin bat etorriko litzateke, beharrizan egoeran aurkitzen den populazioaren zati bat boluntarioekin harremanetan jartzean datzana. Era berean, Gottllieb-ek (1988) proposatzen duen maila didaktikoko esku-hartzearekin bat etorriko litzateke. Pertsonen gizarte sarea txikia eta homogeneoa denean, eta ondorioz bertatik jaso dezaketen gizarte laguntasuna mugatua denean martxan jartzen diren jarduerak lirateke, eta IKEDAM ohiekin horixe gertatzen da hain zuzen. Hel- 
burua bezeroak boluntarioki konpainia, aholkua eta laguntasuna emateko prest agertzen diren komunitateko kideekin harremantzea izan ohi da (Froland et al., 1981; Hernández et al., 2006), eta horixe litzateke izebek egiten dutena.

Printzipioz adin txikikoei soilik bideratutako proiektua bada ere, eta beraz ezingo litzateke emantzipazio baliabidetzat hartu, koordinatzaileak kasu gehientsuenetan gazteak 18 urte bete ostean ere harremanak mantendu egiten direla baieztatzen du. Horrela bada, datorren atalean Izeba proiektuan parte hartzeko aukera izan duten gazte etorkinen egoera aztertzen da, izebengandik jasotzen duten laguntasunak euren gizarteratze prozesuetan nola eragiten duen ezagutzeko asmoz.

\subsection{Izeben papera IKEDAM ohien gizarteratze prozesuan}

Programa ezberdinetako tekniko eta hezitzaileek IKEDAM ohiek izeben aldetik jasotzen duten laguntasunaren garrantzia azpimarratzen dute, batik bat gazte horiek adin nagusitasuna bete eta haurtzaroaren babeserako baliabideetatik at gelditzean.

Ha habido izebas que se han implicado muchísimo y gracias a ellos los chavales han conseguido tirar para delante, ¿eh? [...] se ha conseguido que chicos entrasen a pisos, gracias a que los izebas han presionado, o... izebas se han puesto en contacto con nosotros para hacer seguimientos a chicos porque veían que lo necesitaban, o izebas que... que han encontrado curro a chavales, o... (E17)

\subsubsection{Izeben aldetik jasotako gizarte laguntasuna}

\subsection{1.a. Laguntasun instrumentala}

Gazteek enpleguaren bilaketan zuzeneko laguntza jasotzen dute, izebetariko askok enpresa desberdinetan kurrikulumak banatzera lagundu diete, gomendio gutunak egin dizkiete edota enpresariarekin zuzenean harremanetan jarri dira gaztea gomendatu eta lanerako aukera bat eman diezaioten. Kasu askotan, laguntasun hori funtsezkoa izan da lanpostu bat eskuratzeko orduan.

Hay que apadrinarles en ese sentido un poco, ¿no? Sobre todo a la empresa que quiere contratarles decirle "que me hago yo responsable", o sea, es importante decir a la empresa "mira pues le conocemos desde hace cuatro años, mira, tiene estos..." los pros y los contras, les explicas, les dejas claro y "oye, no hay ningún compromiso, si no se porta bien, o lo que sea”. Todo, en fin, como uno más, pero no es uno más, porque claro, es tan costoso hacerles un contrato a ellos, que no es uno más, hay que empujar... (E12).

Etxebizitza bilatzeko ere zuzeneko laguntza eskaintzen diete, emantzipazio pisu batetara sarbidea izan dezaten edota gela bat alokatu dezaten. Eta proiektuko koordinatzaileak dioenez, zenbaitzuk euren etxeetan ere hartu dituzte denbora batez, bizitzeko beste leku bat bilatu bitartean; izan ere, etxean hartuko ez balituzte kalean geratuko lirateke, izebarik ez duten beste hainbat gazteren kasuan gertatu den moduan. 
Yo en la calle no he estado porque yo tengo esta familia de acogida aquí, bueno mis izebas, que me ayudan mucho. A mi me han dado las llaves de casa y todo, y me dicen que puedo ir cuando quiera (E25).

Dimentsio juridikoan ematen dieten laguntasuna ere oso esanguratsua da. IKEDAM ohietariko asko izeben etxeetan erroldatuta daudela aipatzen du proiektuko koordinatzaileak, izan ere, baimenak berritu ahal izateko beharrezkoa da etxebizitza batean erroldatuta egotea. Horrez gain, dokumentuak berritzera ere laguntzen diete beharrezkoa den kasuetan. Eta oso esanguratsuak diren kasu konkretuak ere aipatzen ditu Izeba proiektuko koordinatzaileak; esaterako, izeba batek gaztea bere diru irabazietan partaide egin zuen, horrela, baimenak berritzea tokatzen zitzaion unean bitarteko ekonomiko nahikoa zituela frogatu ahal izateko, legediak ezartzen duen moduan ${ }^{10}$. Edo are bereziagoa den kasu bat, zeinetan IKEDAM ohi bat bere izebek jolasten zuten futboleko beterano talde batean jolasten hasi zen, eta talde horretako kideek etorkin gaztea baimenak berritzeko zailtasunekin aurkitzen zela jakin zuten unean etxe-langile gisa kontratatzea erabaki zuten, kide bakoitza Gizarte Segurantzari zegozkion 20 euro ordaintzeko erantzukizuna hartuz. Azken ekintza honek agerian uzten du Izeba proiektuak izeben gizarte sarea eta orokorrean gizartea sentsibilizatzeko balio duela, gazte hauen egoera gertutik ezagutzeko aukera emanez.

Azkenik, harrera gizarteko hizkuntza ikasi eta praktikatzeko aukera ere ematen du izebekin harremanetan egoteak, gaztelera zein euskera.

Luego, el idioma también, al final, en vez de estar siempre hablando árabe con sus amigos del centro, pues conmigo, mis amigos, mi familia y tal, tiene que hablar castellano y yo sobre todo al principio le notaba un montón, le decía “iJolín, cómo estás mejorando con el castellano!” (E21). Me han enseñado unas palabras, “gabon”, buenas noches, dónde vas... Si sabes euskera tienes más oportunidades. Si yo tengo una empresa en Marruecos, si tú vienes, eres vasca, pero si hablas en mi idioma, pues más fácil. Hay algunas veces que le dices "barkatu" cuando le preguntas, y así... ellos también ven que sabes algo, que te esfuerzas (E25).

\subsection{1.b. Informaziozko laguntasuna}

Harrera gizarteko enplegu edota etxebizitza aukerei buruzko informazioa ere jasotzen dute izeben aldetik.

Sí, me dan muchos consejos, porque... Siempre le vienes a contar, y te dice que tienes que hacer esto, esto, por ejemplo para encontrar trabajo, o un piso, u otros temas. $\mathrm{Y}$ uno recibe consejos, uno... reflexiona... piensas cómo hacer, y así pues todo es más fácil (E24).

Baina batik bat, izebekin (eta horien lagun zein senideekin) harremantzeak informazio kulturalaren trukaketa ahalbidetzen du. IKEDAM ohiek harrera gizarteko kultura eta ohiturak gertuagotik ezagutzeko aukera dute, eta baita euren jatorrizko kultura bertako jendeari ezagutaraztekoa ere.

${ }^{10}$ Ibídem. 
Hemos aprendido a ser más humanos, a escuchar, no precipitar, mantener el hilo sin romper, eh... y luego también entender las distintas culturas, las distintas formas de ver el mundo, eh... luego también, eh... también para la familia (extensa), es decir, bueno, oye que aquí hay estos temas y que bueno, que tenemos que abrirnos más... También ese acercamiento a la cultura marroquí, comer la carne halal, ir a comprar a la carnicería halal y... descubrir pues restaurantes marroquíes, o sea... que yo si no hubiera estado él, no habría ido. (E12)

Koordinatzaileak eta Izeba proiektuko erabiltzaile izan diren elkarrizketatuek aipatzen duenez, izeba ugari gaztearekin Marokora (edo beste jatorrizko herrialde batetara) joan dira bere familia eta ohiturak ezagutzera, horrek kulturarteko kontaktua eta ulermena gehitzen dituelarik.

Sí, creo, tres veces han ido conmigo a Marruecos. Una vez bajaron solos, han estado en mi casa en Marruecos en Asilah. Y fuimos en Navidad, antes de Navidad fuimos los tres, su hija, la Izaskun, y su novio, y su hija fue también, hemos estado como una semana, y después eh... paso no se cuántos, seis meses o siete meses, bajaron ellos a Marruecos otra vez. Ellos también conocen mis hermanos, conocen mis hermanos y todos, mi familia (E24).

\subsection{1.c. Emoziozko laguntasuna}

Amaitzeko, izebekin harremanetan jarraitzen duten IKEDAM ohiek konfidantza eta segurtasuna ematen dietela aipatzen dute, baita maitasuna eta afektua ere. Asko eskertzen dute entzuten dien norbait izatea, eta baita euren egoeraz arduratzen den norbait dutela sentitzea ere. Guzti horrek aurrera jarraitzeko indarra ematen dietela aipatzen dute gazteek.

Pffff, una cosa muy importante para mi, ¿eh? Sí, para todos, porque siempre que los he necesitado han estado ahí, estaban ahí siempre, a buenas o a malas, cuando me portaba bien o cuando me portaba mal, han estado ahí. Y ha sido lo mejor para mi, así... (E13).

Sí, la verdad. Pues bueno, te dan seguridad, ¿sabes? Cariño... te tratan de otra manera como diferente, como especial, ¿sabes? Yo siempre que voy, me gusta mucho el pescado, y cuando voy a su casa siempre me tiene pescado preparado y así, gambitas y así, eh... pulpo a la gallega, no sé qué... porque es también, es una mujer mayor y... me trata muy bien. Eso es más importante que el tema económico, ¿sabes? Porque... Animación, te dan energía para poder seguir (E24).Cuando te mete a su casa y te da llaves, te dan confianza. Es como te he dicho antes, si me pasa algo, si me llevan al calabozo o cualquier cosa... es como ellos se preocupan de mi, ¿sabes? Imagínate, estás enfermo, ¿quién te va a cuidar?, o ¿quién se va a preocupar?, ¿quién?. Pues yo tengo a ellos (E25).

\subsubsection{Izeben gizarte laguntasuna IKEDAM ohien gizarteratze prozesuan}

Izeben aldetik jasotzen duten gizarte laguntasunak gizarteratzeari dagozkion esparru eta dimentsioetan laguntzen die gazte etorkinei (3. Taula). Enplegua eta etxebizitzaren bilaketan eta prozedura legalekin eskaintzen dieten laguntasun instrumentalak horien gizarte- 
ratze sozio-estrukturala errazten du. Hizkuntzarekin jasotzen duten laguntasunak berriz esparru soziokulturalaren baitako dimentsio kulturalean laguntzen die.

Informaziozko laguntasunak ere gizarteratze esparruetan egokitzen laguntzen die. Harrera gizarteko lan eta etxebizitza aukeren inguruan jasotzen duten informazioa esparru sozio-estrukturalaren baitako dimentsio soziokulturalean aurrera egiteko baliagarria suertatzen zaie; harrera gizarteko kultura ezagutu eta autoktonoei euren jatorrizkoa azaltzeak berriz esparru soziokulturalaren baitako dimentsio kulturalean laguntzen die, kulturartekotasunean oinarritutako gizarteratze prozesu bati jarraitzea ahalbidetzen dielarik. Elkar ezagutza horrek bestearekiko sentsibilitate gehiago izatea ere errazten du, dimentsio identitarioan lagunduko diena.

Azkenik, izebek igortzen dieten emoziozko laguntasunak gazte hauen gizarteratze soziokulturala faboratzen du. Jasotzen duten afektuak, konfiantzak eta segurtasunak autoktonoekiko ikuspuntu positiboago bat garatzen laguntzen die IKEDAM ohiei. Nahiz eta izebekin harremantzen diren mutikoek ere harrera gizartearen aldetik jarrera arrazistak jasotzen jarraitzen duten normalki, ukapen sentimendua ez da hain nabarmena, izan ere, gutxienik komunitatearen zati batengandik maitatuak eta errespetatuak sentitzen dira. Izeben ingurua sentsibilizatuz doa eta kontrako jarrerak gutxituz doaz, lan honetan zehar aurkeztu diren laguntasun eta solidaritatezko adibideek argi erakusten duten moduan. Horrela bada, nahiz eta oraindik goizegi izan daitekeen gizarteratze identitario batez hitz egiteko, Izeba proiektuko erabiltzaile ohiei egindako elkarrizketek erakutsi dute gazte horiek proiektuan parte hartzeko aukerarik izan ez dutenak baino gusturago sentitzen direla harrera gizartean.

Taula 3. Izebengandik jasotako gizarte laguntasunak IKEDAM ohien gizarteratze esparru eta dimentsioetan duen eragina

\begin{tabular}{|c|c|c|}
\hline \multirow[t]{2}{*}{$\begin{array}{l}\text { LAGUNTASUN } \\
\text { INSTRUMENTALA }\end{array}$} & $\begin{array}{ll}\text { - } & \text { Enplegua aurkitzeko zuzeneko laguntza } \\
\text { - } & \text { Etxebizitza bilatzeko zuzeneko laguntza } \\
\text { - } & \text { Prozedura legaletan zuzeneko laguntza }\end{array}$ & $\begin{array}{l}\text { GIZARTERATZE SOZIO- } \\
\text { ESTRUKTURALA } \\
\text { (dimentsio } \\
\text { sozioekonomikoa eta } \\
\text { juridikoa) }\end{array}$ \\
\hline & $\begin{array}{l}\text { - Harrera gizarteko hizkuntzarekin zuzeneko } \\
\text { laguntza }\end{array}$ & $\begin{array}{l}\text { GIZARTERATZE } \\
\text { SOZIOKULTURALA } \\
\text { (dimentsio kulturala) }\end{array}$ \\
\hline \multirow{2}{*}{$\begin{array}{l}\text { INFORMAZIOZKO } \\
\text { LAGUNTASUNA }\end{array}$} & $\begin{array}{ll}\text { - } & \text { Harrera gizarteko enplegu aukerei buruzko } \\
\text { informazioa } \\
\text { - } \quad \text { Etxebizitza aukerei buruzko informazioa }\end{array}$ & $\begin{array}{l}\text { GIZARTERATZE SOZIO- } \\
\text { ESTRUKTURALA } \\
\text { (dimentsio } \\
\text { sozioekonomikoa) }\end{array}$ \\
\hline & $\begin{array}{ll}\text { - } & \text { Harrera gizarteko ohiturei buruzko } \\
\text { ezagutzak jaso } \\
\text { - } \quad \text { IKEDAM ohien jatorrizko ohiturei buruzko } \\
\text { informazioa igorri }\end{array}$ & $\begin{array}{l}\text { GIZARTERATZE } \\
\text { SOZIOKULTURALA } \\
\text { (dimentsio kulturala eta } \\
\text { identitarioa) }\end{array}$ \\
\hline $\begin{array}{l}\text { EMOZIOZKO } \\
\text { LAGUNTASUNA }\end{array}$ & $\begin{array}{l}\text { - } \quad \text { Entzunak izatea, euren egoerarekiko } \\
\text { arduratzen den norbait izatea, konfiantza } \\
\text { eta segurtasuna } \\
\text { - } \quad \text { Maitasuna eta afektua } \\
\text { - } \quad \text { Aurrera egiteko indarra }\end{array}$ & $\begin{array}{l}\text { GIZARTERATZE } \\
\text { SOZIOKULTURALA } \\
\text { (dimentsio identitarioa) }\end{array}$ \\
\hline
\end{tabular}

Iturria: Egileak eginda. 
2. Irudian izebek gazte etorkinen gizarteratze prozesuak laguntzeko eragile gisa betetzen duten paper garrantzitsua ikus daiteke. Hasteko, izeba familia batekin harremantzeak euren gizarte sarea zabaldu eta heterogeneoagoa bihurtzea eragiten du, eta bertatik gizarte kapital gehiago eskuratzea ahalbidetu. Enpleguarekin jasotzen duten laguntzak lanpostu bat eskuratzeko aukerak gehitzen dizkie, eta zenbait kasutan laguntasun horri esker gazteek lanpostu bat eskuratu dutela ikusi da. Horrek egoera juridiko erregularra eta oinarrizko gastuei aurre egiteko diru sarrerak izatea ahalbidetzen die, eta baita lan harremanak edota komunitatearekin harremanak gauzatzeko aukera ere. Harreman horiek are gehiago zabalduko dute euren gizarte sarea eta gizarte kapitala metatzeko aukerak gehitu. Hala ere, gaur egungo testuingurua kontrakoa denez baliteke izeben laguntza jasota ere lanposturik ez eskuratzea. Baina edonola ere, prozedura legalekin jasotzen duten laguntza dela eta gazte hauen gehiengoa egoera juridiko erregularrean mantentzen da, horrek komunitate hartzailearekin lasaitasunez harremantzea ahalbidetzen dielarik, poliziak harrapatu eta jatorrizko gizartera bidaltzeko beldurrik gabe, eta harreman horietatik gizarte kapitala eskuratu dezakete. Eta orokorrean, gizarteratzeari dagozkion esparru eta dimentsio ezberdinetan jasotzen duten laguntasun guztiak IKEDAM ohiak autoktonoen aldetik maitatuak eta errespetatuak sentitzea eragiten du, eta bi kolektiboak islatzen diren identitate amankomun baten agerpena erraztu.

Irudia 2. Izebak IKEDAM ohien gizarteratzearen eragile/laguntzaile

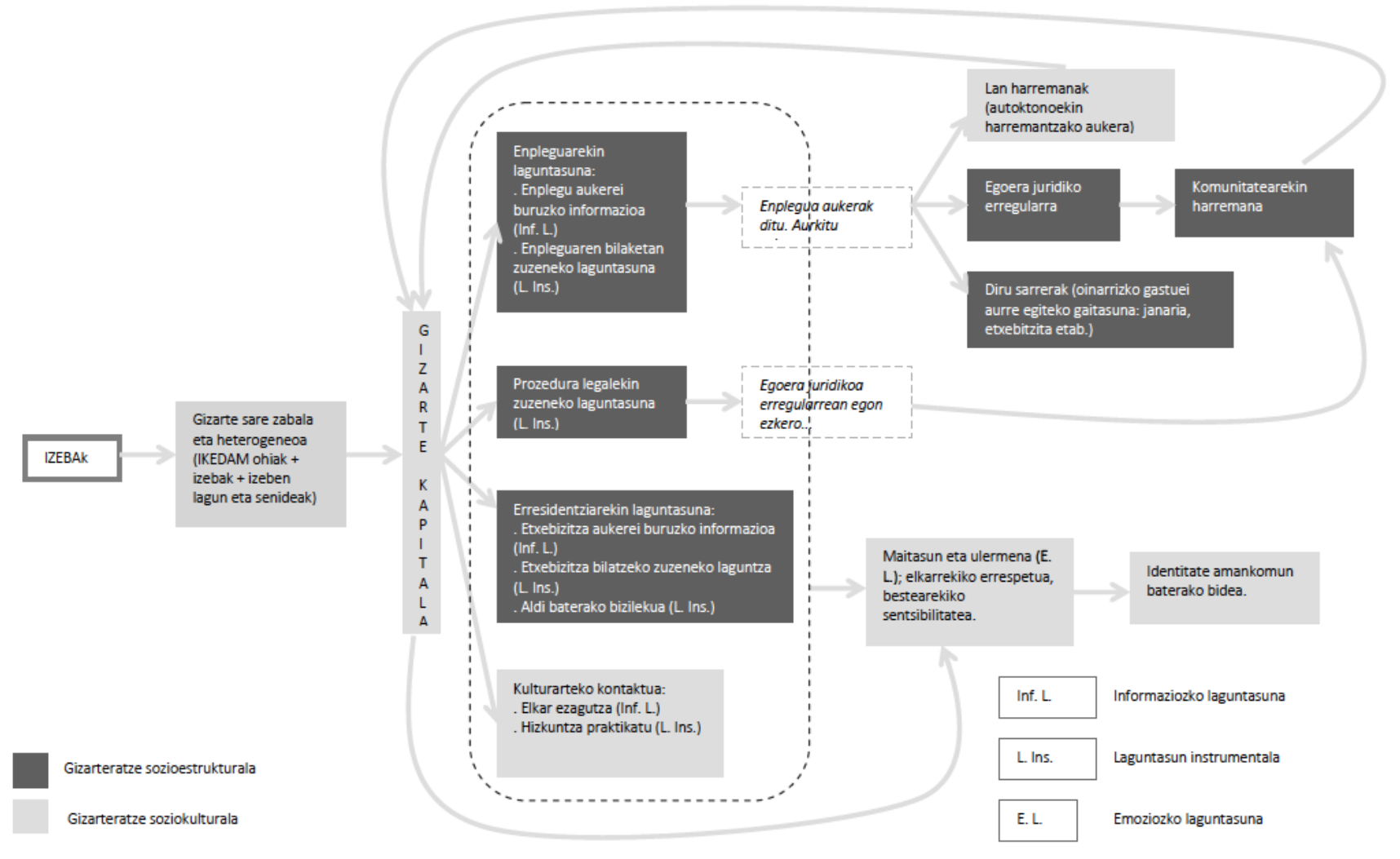

Iturria: Egileak eginda. 


\section{ONDORIOAK ETA GOMENDIOAK}

Ikerketa honek argi erakutsi du gaur egungo krisi ekonomikoak gazte etorkin tutelatu ohien gizarteratze eredu tradizionala kolokan jartzea eragin duela. Krisi ekonomikoaren aurretik gazte hauen gehiengoak erraztasunez lortzen bazuen lanpostu bat, gaur egun oso gutxi dira enplegu bat eskuratzen dutenak.

Enplegua etorkinen gizarteratze prozesuak ahalbidetzeko tresna eraginkorra izan da oparotasun ekonomikoko garaian. Lanpostu bat izateak esparru sozio-estrukturalari dagokion gizarteratzea errazten du alde batetik: diru sarrerak bermatzen ditu, zeintzuekin bizitzako oinarrizko gastuei aurre egin ahalko zaien, hala nola, janaria, arropa, etxebizitzaren alokairua etab.; eta egoera juridiko erregularra eskaintzen du. Eta era berean, gizarteratze soziokulturala ere ahalbidetzen du: egoera juridiko erregularrean egonik ez dute poliziaren jazarpena dela eta kalera ateratzeko beldurrik izango, eta horrek komunitateko kideekin harremantzea posible egingo die; egunero lantoki batetara joateak bertako jendearekin erlazionatzeko aukera ere emango die; eta autoktonoekin harremantzeak euren gizarte sarea zabaltzeko eta heterogeneoagoa bihurtzeko aukera eskainiko die, horrek gizarte kapital handiagoa metatzea ahalbidetuko dielarik. Alde batetik, gizarteratze soziokulturala ahalbidetuko duen kulturarteko kontaktua, elkar ezagutza eta errespetua, eta hizkuntza autoktonoa praktikatzeko aukera. Eta bestetik, gizarteratze sozio-estrukturalari dagokion laguntasun instrumentala zein informaziozkoa, lan edo etxebizitza aukerei buruzkoa esaterako. Guzti horrek bi kolektiboen arteko sentsibilizazio maila gehitzea eragingo luke, gazte etorkinak harrera gizartean hobeto sentitzea eta identitate amankomun baten agerpena errazago gertatzea. Aitzitik, langabezia tasa erabat hazi eta lanpostu bat eskuratzea ezinezkoa ez bada oso zaila bilakatu den gaur egungo testuinguruan, badirudi enpleguak ezin duela IKEDAM ohien gizarteratzea bultzatzeko tresna bakarra izaten jarraitu, eta beraz, ez da nahikoa izango norabide horretan soilik lan egitea.

Emantzipazio baliabideak aztertzerakoan ikusi denez, horiek soilik gizarteratzearen esparru sozio-estrukturalean eragiten jarraitzen dute: emantzipazio pisuetara sarbidea ahalbidetzen zaie, diru-laguntzak kudeatzen zaizkie, baimenak berritzen laguntzen zaie eta formakuntza eskaintzen zaie. Horrela, denbora tarte batean egonkortasun sozioekonomikoa eskuratzen dute gazte migratzaileek, baina argi geratu da baliabide horiek izaera paliatiboa dutela, izan ere, horiek erabiltzeko gehieneko epea amaitu ostean, eta lanposturik aurkitu ez badute, berriro ere adin nagusitasuna bete zuteneko egoera berean aurkitzen dira, euren gizarteratze prozesuak etenda eta gizarte bazterkeria arrisku handiekin. Horrela bada, badirudi emantzipazio baliabideak ez direla gaur egungo testuinguru sozioekonomikora egokitu, horrek IKEDAM ohien gizarteratze prozesuak zaildu egiten dituelarik. Argi dago ez duela zentzurik adin txikiko diren bitartean eta adin nagusitasuna bete ostean ere gazteek burututako esfortzu pertsonala eta administrazioak egindako inbertsio ekonomikoa alferrikakoak suertatzea. Beraz, beharrezkoa izango da bestelako helburuak dituzten baliabideetan pentsatzen hastea.

Azkenik, adin txikiko ziren bitartean Izeba proiektuan parte hartzeko aukera izan zuten gazte migratzaileek gizarteratze egoera hobeagoa aurkezten dutela ikusi da. Izebek lagun- 
tasun instrumentala, informaziozkoa eta emoziozkoa eskaintzen diete, gizarteratzearen esparru eta dimentsioetan aurrera egiteko oinarria ematen diena. Zentzu horretan, argi gelditzen da Hernández et al. (2006) edota Martínez et al.-ek (2011) azpimarratzen duten moduan etorkinen gizarteratzea bermatzeko eraginkorra izan daitekeela horien gizarte sareetan eragitea, normalki horien sareak txikiak eta homogeneoak izan ohi direlako eta gizarte kapital gutxi izaten dutelako eskuragarri. IKEDAM ohien kasuan horixe ikusi da, euren gizarte sarea txikia izan ohi dela eta batik bat aberkideek eratzen dutela. Horrela bada, Izeba proiektuak gazte etorkinen gizarte sarea zabaldu eta heterogeneoagoa bihurtzen du eta horrek gizarte laguntasuna jasotzeko aukerak gehitzen dizkie, euren gizarteratze prozesuak bermatzeko funtsezkoa suertatzen dena.

IKEDAM ohiek izebengandik jasotzen duten laguntasuna ikusita, halako proiektuen garapena gazte migratzaileek gizarteratze prozesuan aurkitzen dituzten zailtasun anitzei aurre egiteko bide aproposagoa litzatekeela dirudi. Hori dela eta, Gipuzkoaz haratago, gainontzeko lurralde historikoetara, hots Araba eta Bizkaira, ere zabaldu beharreko baliabidea dela irizten da, edo zergatik ez, baita estatuko beste autonomia erkidego batzuetara ere. Era berean, erabiltzaileen adin tarteak handitzea komenigarria litzatekeela uste da, ez daitezela izan soilik adin txikikoei bideratutako programak Izebaren kasuan gertatzen den moduan, emantzipazio baliabide gisa ere txertatu daitezela, horrela autoktonoekin harremantzeko aukera adin txikikoek ez ezik adin nagusitasunera iritsi direnei ere emanez, Kataluniako Punt de Referencia-ren baitako Referents programaren ${ }^{11}$ kasuan bezala. Izan ere, hain justu adin nagusitasuna betetzen dutenean aurkitzen dira gazte migratzaile hauek egora zailenean, ordura arte babesa ematera behartuta zegoen administrazio publikoa jada eginkizun horretatik salbuetsita gelditzen baita.

Hala eta guztiz, halako esku-hartzeak martxan jartzeak kontutan izan beharreko zenbait arrisku edo zailtasun eragin ditzake. Alde batetik, zerbitzu publikoetan murrizketak egiteko erabiliak izan daitezke, laguntasuna eta arreta eskaintzeko erantzukizun osoa etorkinen gizarte sare informalari igorriz (Hernández et al., 2006). Hori dela eta, beharrezkoa izango da programa hauek IKEDAM ohien gizarteratze prozesuak laguntzeko asmoz burutzen diren beste ekintza batzuen osagarri eta ez ordezko gisa garatzea. Bestalde, baliteke autoritate publikoak halako estrategiak martxan jartzearen aurka agertzea, gazte etorkinen artean dei efektua eragingo luketela uste izanda. Zenbait ikerketek erakutsi dute estatuak autonomia erkidegoei zeregin bikoitza egozten diela: "Explícitamente se les reclama que los protejan desde los Servicios de Protección a la Infancia, mientras implícitamente se les responsabiliza de evitar el efecto llamada” (Gimeno, 2003: 16). Inplizituki ezartzen zaien eginkizun horrek Izeba bezalako programarik martxan ez jartzera eraman ditzake autonomia erkidegoak.

\footnotetext{
${ }^{11}$ Punt de Referencia izeneko entitatea 1997an sortzen da, Katuluniako Generalitat-aren tutelapean adin txikikoentzako zentroetan bizi ostean euren heldu bizitzari bakarrik ekin behar izan dioten gazte tutelatu ohien kolektiboari akonpainamendu eta laguntasuna eskaintzeko asmoz. Entitate honek gazteei Referents izeneko programan parte-hartzeko aukera ematen die, zeinak erreferentzi gisa balioko dion autoktono heldu batekin harremantzeko aukera ematen dien.
} 


\section{BIBLIOGRAFIA}

Arango, J. (2007). Las Migraciones internacionales en un mundo globalizado. Vanguardia Dossier, 22 zbk., 6-15 or.

Ararteko (2005). Bakarrik dauden adingabeko atzerritarren egoera EAEn. Vitoria-Gasteiz: Ararteko.

Ararteko (2011). Arrisku egoera berezietan dauden adingabeak. Vitoria-Gasteiz: Ararteko.

Ararteko (2013). Recomendación general 5/2013 del Ararteko, de 17 de junio. Garantías en la atención a los menores/jóvenes extranjeros no acompañados. Eskuragarri http:// www.ararteko.net/RecursosWeb/DOCUMENTOS/1/0_3081_3.pdf

Ararteko (2014). Eusko legebiltzarrarentzako urteko txostena 2013. Haur eta Nerabeentzako Bulegoaren txostena. Vitoria-Gasteiz: Ararteko.

Ararteko (2015). Eusko Legebiltzarrarentzako urteko txostena 2014. Haur eta nerabeentzako bulegoaren txostena. Vitoria-Gasteiz: Ararteko.

Bernat, J.S., Agost, M.R., Fuertes, A.M., Fuertes, I., Montañés, C., Bucur, E.R. eta Soto, G. (2010). Estudio del capital social a partir de las redes sociales y su contribución al desarrollo socioeconómico: el colectivo de inmigrantes rumanos en la provincia de Castellón. Cuadernos de Investigación 13 zbk. Valentzia: CeiMigra Fundazioa.

Blanco, C. (1990). La integración de los inmigrantes en Bilbao. Bilbo: Bilboko Udala.

Blanco, C. (2001). La integración de los inmigrantes. Fundamentos para abordar una política global de intervención. Revista Migraciones, 10 zbk., 207-248 or.

Bourdieu, P. (1986). The forms of capital. In Richardson, J.G. (ed.) Handbook of Theory and research for the sociology of education (241-258 or.). New york: Greenwood Press.

Bravo, A., Santos, I. eta Del Valle, J.F. (2010). Revisión de actuaciones llevadas a cabo con menores extranjeros no acompañados en el Estado Español. Oviedo: Consejería de Bienestar Social y Vivienda. Gobierno del Principado de Asturias.

Castel, R. (1992). La inserción y los nuevos retos de las intervenciones sociales. In Álvarez-Uría, F. (biltz.), Marginación e inserción. Los nuevos retos de las políticas sociales (25-36 or.). Madril: Endymión.

Castel, R. (1995). La metamorfosis de la cuestión social. Una crónica del asalariado. Paris: Fayard.

Colectivo Ioé (2008). Inmigrantes, nuevos ciudadanos: ¿hacia una España plural e intercultural? Madril: FUNCAS-Fundación Cajas de Ahorros Confederadas. 
Coleman, J. (1988). Social capital in the creation of human capital. American Journal of Sociology, 94 bol., 95-120 or.

Coleman, J. (1990). Foundations of Social Theory. Cambridge: Harvard University Press.

EDE Fundazioa (2011). Relaciones de solidaridad entre inmigrantes: acercamiento a las redes informales de apoyo de menores y jóvenes no acompañados en la CAPV. Bilbo: EDE Fundazioa.

EDE Fundazioa (2012). Experiencias de solidaridad de jóvenes migrantes: la integración social a través del voluntariado. Bilbo: EDE Fundazioa.

Forni, P., Siles, M., eta Barreiro, L. (2004). ¿Que es el Capital Social y cómo Analizarlo en contextos de Exclusión Social y Pobreza? Estudios de Caso en Buenos Aires, Argentina. JSRI-Julian Samora Research Institute, $35 \mathrm{zbk}$.

Froland, C., Pancoast, D.L., Chapman, N.J. eta Kimboko, P. (1981). Linking formal and informal support systems. In Gottlieb, B.H. (biltz.), Social networks and social support (259-277 or.). Londres: Sage.

Fuertes, A.M., Agost, M.R., Fuertes, I. eta Soto, G. (2013). Las aportaciones del apoyo social al capital social: propuesta de un modelo integrado y convergente. CIRIEC-España, Revista de Economía Publica, Social y Cooperativa, 77 zbk., 155-188 or.

Gimeno, Ch. (2003). Trabajo Social y control migratorio. Tensiones en los Sistemas de Protección de Menores. Portularia, 13 bol., 2 zbk., 15-24 or.

Gobierno Vasco (2009). Drogodependencia en menores extranjeros no acompañados (MENA): su derecho a una educación y salud de calidad. Vitoria-Gasteiz: Gobierno Vasco.

Gonzalo, A., Jiménez, E. eta Vozmediano, L. (2010). Adingabeak edo atzerritarrak? Esku hartzeko politiken azterketa, lagundu gabeko adingabe atzerritarren gainekoa. Vitoria-Gasteiz: Ararteko.

Gottlieb, B.H. (1988). Support interventions: A typology and agenda for research. In Duck, S.W. (ed.), Handbook of personal relationships (519-541 or.). New York: John Wiley \& Sons.

Gracia, E., Herrero, J. eta Musitu, G. (1995). El apoyo social. Bartzelona: PPU-Promociones y Publicaciones Universitarias.

Hernández, S., Alonso, E. eta Pozo, C. (2006). Social Support Interventions in Migrant Populations. British Journal of Social Work, 36 bol., 7 zbk., 1151-1169 or.

Jiménez, M. (2005): La migración de los menores en Marruecos. Reflexiones desde la frontera sur de Europa. In Ramírez, A. eta Jiménez, M. (koord.), Las otras migraciones: La emigración de menores marroquíes no acompañados a España. (115-133 or.) Madril: Akal. 
Martínez, M., García, M., Maya, I., Rodríguez, S. eta Checa, F. (1996). La integración social de los inmigrantes africanos en Andalucía. Necesidades y recursos. Sevilla: Junta de Andalucía.

Martínez, M.F., Calzado, V., eta Martínez, J. (2011). Intervención social y comunitaria en el ámbito de la inmigración. In Fernández, I., Morales, J.F. eta Molero, F. (koord.), Psicología de la intervención comunitaria (245-288 or.). Bilbo: Desclée De Brouwer.

Maya, I. (1999). Análisis de los recursos de apoyo social de los inmigrantes africanos y latinoamericanos en Andalucía. Tipología de redes y proceso de adaptación. Doktoradutza tesia, Sevillako Unibertsitatea.

Maya, I., Martínez, M. eta García, M. (1999). Cadenas migratorias y redes de apoyo social de las mujeres peruanas en Sevilla. Demófilo, 29 zbk., 87-105 or.

Mazkiaran, M. (2011). Menores extranjeros no acompañados tras las últimas reformas legislativas. Mugak, 56 zbk., 24-28 or.

Moreno, G. (2012). Actitudes y opinión sobre los menores extranjeros no acompañados en la Comunidad Autónoma del País Vasco. Migraciones, 31 zbk., 43-68 or.

Putnam, R. (1993). Making Democracy Work. New York: Princeton University Press.

Quiroga, V. (2003). Els petits Harraga. Menors immigrats irregulars no acompanyats d'origen marroquí a Catalunya. Doktoradutza tesia, Universitat Rovira i Virgili.

Quiroga, V., Alonso, A. eta Armengol, C. (2005). Rutas de pequeños sueños: Los menores migrantes no acompañados en Europa. Bartzelona: Fundació Pere Tarrès.

Quiroga, V., Alonso, A. eta Sòria, M. (2009). Sakelako ametsak: Inoren kargura ez dauden adingabe migratzaileak Euskal Autonomia Erkidegoan. Vitoria-Gasteiz: Eusko Jaurlaritzaren Argitalpen Zerbitzu Nagusia.

Quiroga, V., Alonso, A. eta Sòria, M. (2010). Sueños de bolsillo: Menores Migrantes No Acompañados/as en España. Bartzelona: Unicef eta Banesto.

Quiroga, V., Alonso, A. eta Sòria, M. (2011). Los menores en contextos migratorios. Evolución estadística del fenómeno (1993-2009). In Revilla, M. (koord.), Infancia, juventud y migraciones: una mirada para la cooperación internacional (177-205 or.). Madril: Siglo XXI.

Ruiz Olabuénaga, J.I. (1996). Metodología de investigación cualitativa. Bilbo: Deustuko Unibertsitatea.

Ruiz Olabuénaga, J.I. eta Blanco C. (1994). La migración vasca. Análisis trigeneracional de 150 años de inmigración. Bilbo: Deustuko Unibertsitatea. 
Senovilla, D. (2007). Situación y tratamiento de los menores extranjeros no acompañados en Europa. Brusela: Observatorio Internacional de Justicia Juvenil.

Solé, C., Alcalde, R., Pont, J., Lurbe, K. eta Parella, S. (2002). El concepto de integración social desde la sociología de las migraciones. Migraciones, 12 zbk., 9-41 or.

Suárez, L. (2006). Un Nuevo actor migratorio: jóvenes, rutas y ritos juveniles transnacionales. In Checa, F., Checa J.C., eta Arjona, A. (ed. lit.), Menores Tras la Frontera. Otra Emigración que Aguarda (17-50 or.). Bartzelona: Icaria.

Subirats, J. (zuz.) (2004). Pobreza y exclusión social. Un análisis de la realidad española y europea. Bartzelona: "La Caixa” Fundazioa.

Unicef eta CGAE (Consejo General de la Abogacia Española) (2009). Ni ilegales ni invisibles: Realidad jurídica y social de los Menores Extranjeros en España. Madril: Etnia Comunicación. 